Historic, Archive Document

Do not assume content reflects current scientific knowledge, policies, or practices. 

FEB 141929

SLIP ME OVER A TACK HOLD ME FOR REFERENCE

$=19295$

Descriptive Catalogue of Leading Varieties of

PeACH TreES

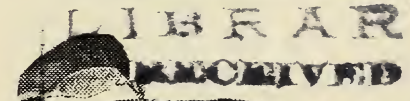
1 ( 1 .

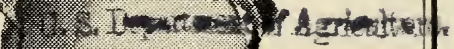

J. C. HALE NURSERY CO.

Established 1895 by J. C. Hale

Winchester, Tenn.

WHOLESALE EXCLUSIVELY

I am a valuable little booklet and you had better keep me 


\section{Compliments of the}

\section{J. C. Hale Nursery Company}

J. C. HALE, Manager

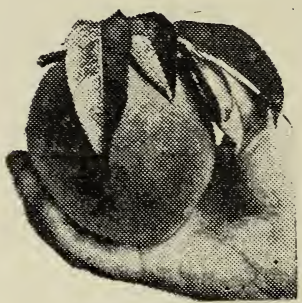

Early Rose

The Largest Exclusive Wholesale Pecch Tree Man in the Country

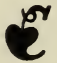

\section{GUARANTEE OF GENUINENESS}

We exercise the greatest care to keep our varieties PURE and TRUE to name, and we hold ourselves in readiness at all times to replace, on proper proof, all stock that may prove otherwise. But it is mutually agreed between the purchaser and ourselves that we shall not at any time be liable for any amount greater than the original price of the goods. 


\section{ANNOUNCEMENT}

To the Trade:

We have been engaged for many years in the Nursery Business, and during this time we have found a growing demand for Peach Trees and especially with the Commercial planters. Trees that are grown in a locality free as far as possible from diseases.

We set about to find such a favorable locality, removed as far as possible from large orchard districts, in a climate especially adapted to growing the young tree. We think we have found this locality, here in Middle Tennessee. We are located in Franklin County, eighty miles southeast of Nashville, forty miles north of Huntsville, Ala., and seventy miles northwest of Chattanooga, on the N., C. \& St. L. Ry., surrounded by the Cumberland Mountain range, giving us a fine air drainage, as well as soil drainage, both of which are very essential to the propagation of nursery stock.

The Natural Wild Mountain seedling peach pits of Tennessee have long been considered the best that can be had for stocks to bud our commercial varieties on, and our peach pits are sought after by the leading nurserymen throughout the country, for planting and growing their stocks from. We beg to call your especial attention to this little descriptive peach catalogue and urge you to preserve same for future reference.

Soliciting your business, we beg to remain, yours very respectfully,

J. C. HALE. 


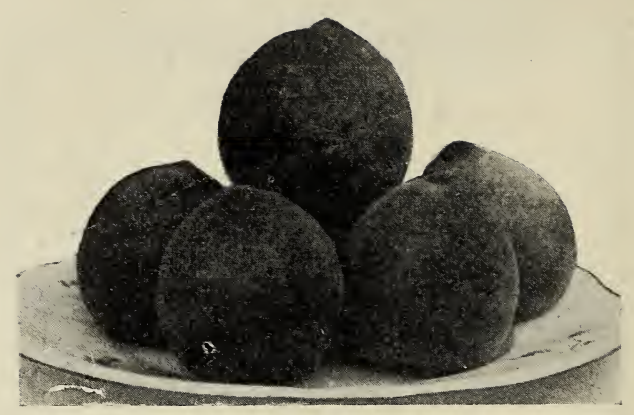

Carman

\section{PEACH TREES}

\section{ONE-YEAR BUDS ON NATIVE SEEDLING STOCK.}

We always carry a large stock of one-year peach, to meet the demands of the Retail Nursery trade. Nurserymen traveling agents will do well to call on us, if in need of heavy, well graded, thrifty peach trees.

\section{JUNE BUDDED PEACH TREES.}

I am the pioneer June Bud man, being amongst the very first to propagate the peach by June budding.

The demand for June Buds by the large Commercial Planters, and especially of the South, has led us to engage actively in this line. Only June Budding in large quantities, a few of the leading commercial varieties, such as Mayflower, Red Bird Cling, Greensboro, Arp Beauty, Slappy, Ea. Bell or Hiley, Carman, Belle of Ga., Elberta, Salway and J. H. Hale.

We also grow in June Bud a general line of varieties, but go heavy on the leaders.

A letter with a $2 c$ stamp on it will catch us and save you money. 


\section{PEACHES}

\section{DESCRIPTIVE LIST OF VARIETIES.}

ALBRIGHT. Albright's Winter. Medium to large, roundish, somewhat pointed; color creamy white, sometimes blushed; cavity narrow and deep; suture slight, extending beyond apex. Flesh creamy white, sometimes with slight red at pit, tender, vinous, good; pit free. Grown in the Southeast, but does well further north. Oregon, North Carolina.

ALEXANDER. Medium in size; skin light-colored with shading and mottling of red. Flesh white, meaty, juicy, sweet; pit nearly free. Season in South about middle of June. Grown for early market. Origin, Illinois.

AMELIA. Large, roundish, narrowing to apex; color creamy white with red cheek; suture extends beyond apex. Flesh creamy white with bright red at pit; mild, tender, pleasant-flavored; pit free. A Carolina variety doing well in Michigan and the Southeast. Freestone; season last of July.

ARP BEAUTY. Yellow, blushed and mottled bright crimson, very attractive; firm, juicy, excellent flavor-an extra good shipper. Tree a strong grower, prolific and hardy, reaching its perfection in Washington, Oregon and the South, especially in Georgia and Alabama. Origin, Texas. Ripens in Georgia about three weeks ahead of Elberta.

BEERS' SMOCK. Medium to large, round; color creamy white with dark-red blush; cavity quite deep; suture distinct. Flesh quite juicy, yellow, with red at pit, rich; quality good; pit free. Commercial. Origin, New Jersey.

BILYEU (Bilyeu's Late). Large, roundish; color greenish white with red cheek. Flesh white, firm, sweet, good; pit free. A very valuable shipping and canning variety on the West Coast and in the States where the season permits its ripening. Origin, Maryland. 
BLOOD CLING. Large to very large, roundish oval; color dark dull, cloud red; suture distinct. Flesh deep red, firm, juicy, but flavor very poor. Use, kitchen, and as a curiosity in market on account of its blood-red flesh.

BOKARA NO. 3. Large, color yellow with red cheek, flesh yellow, firm set, melting, rich; pit free. Grown by the writer from pits received from Bokara in North Central Asia. Popular in Georgia, and the hardiest variety in Iowa.

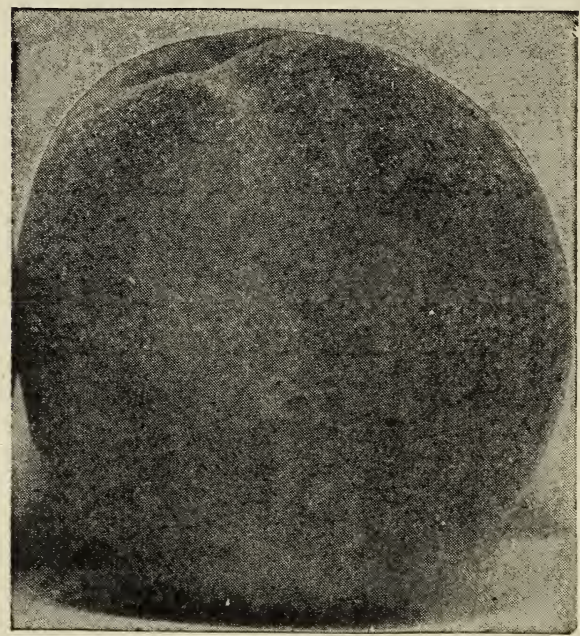

Hiley

BOKARA NO. 1.' Medium to large, oval; color creamy yellow, splashed with red. Flesh yellow with red at the pit; subacid, melting, very good; pit free. Glands many, reniform. A very hardy tree with same history as No. 3 .

BELLE OF GEORGIA. Very large, skin white with red cheek; flesh white, firm, and of excellent flavor; the fruit uniformly large and 
showy; tree a rapid grower and very prolific. A seedling of Chines Cling, originated by Lewis Rumph, Marshallville, Ga. Just a red and white Elberta. Free, season just ahead of Elberta.

BUTLAR'S LATE. Large to very large; color greenish white with red cheek. Flesh white, firm, very good; pit free. Season comes in after Smock and meets a shipping want in the Southwest. Origin, Virginia.

CARMAN. Large, broadly oval, pointed, color white dotted, splashed and flushed with shades of red. Flesh creamy white tinged with red; vinous, sprightly, good. Claimed to have the same origin as Elberta and is largely grown in the South for commercial purposes. Nearly free.

CHAIR'S (Chair's Choice). Large, oval to roundish, tapering to apex; color pale yellow with some blush, and is quite pubecent; suture extends beyond apex; cavity narrow and deep. Flesh yellow, quite acid, red at pit. Season early October in Maryland. A great commercial variety.

CHAMPION. Large, round, nearly regular; color white mottled with red on sunny side; suture extends two-thirds around. Flesh whitish with red at the pit; pit free. Quality nearly best. Origin, Illinois.

CHINES CLING. Large, roundish, somewhat elongated; color pale yellow; suture half round. Flesh white with red at pit; tender, vinous, with trace of peach-bitter. Origin, Delaware.

CRAWFORD'S EARLY. Large, roundish, somewhat elongated; color bright yellow with red cheek and some bloom; in many cases the yellow surface is sprinkled with red specks and the line of suture is compressed; suture extends two-thirds around; cavity broad but shallow. Flesh yellow, juicy, sweet, and colored at pit; quality very good; pit free. Widely grown on lands not specially subject to spring frosts. Origin, New Jersey. 
CRAWFORD'S LATE. Medium to large, roundish oval; color yellow with red cheek. Flesh yellow with red at the pit; melting, vinous, very good; pit free. Grown across the continent. Origin, New Jersey.

CHINES FREE. Large, oblong; skin white, with red cheek; flesh red, firm and well flavored; free from rot, which makes it very desirable market variety; ripens July 5th to 15 th.

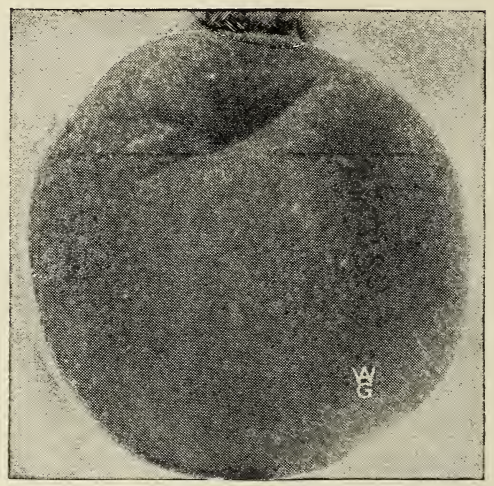

Early Elberta

CAPT. EDES. Resembles Elberta in color and flavor, but tree is hardier, a strong grower and productive. Quality good. Bears when Elberta fails, but the wonderful popularity of Elberta has kept it in the background. When better known it will be wanted by commercial planters. Season just a little earlier than Elberta. Origin, Illinois.

EARLY BELL (Hiley). Large, roundish; color creamy white, with red and crimson cheek. Flesh creamy white, firm, juicy; pit free. A seedling of Belle of Georgia, which ripens its fruit about one month earlier than its parent. Origin, Georgia. 


\section{COMPLIMENTS OF}

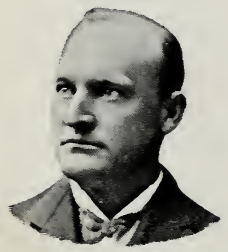

J. C. HALE, Proprietor J. C. HALE

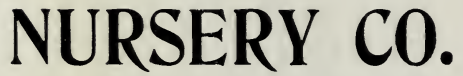

THE LARGEST PEACH TREE NURSERY

IN THE WORLD

REMEMBER ME WHEN YOU GO TO PLACE YOUR ORDER 


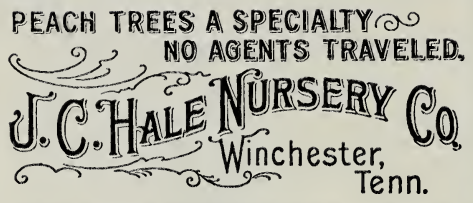

\begin{tabular}{|c|c|c|c|}
\hline \multicolumn{4}{|c|}{-} \\
\hline SMTWTFS & SMTWTFS & SMTWTFS & SMTWTFS \\
\hline IAN & FEE & MAFA & $A F A$ \\
\hline 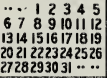 & 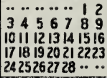 & $\mid \begin{array}{ccccccc}\because & \cdots & \cdots & \cdots & 1 & 2 \\
3 & 4 & 5 & 6 & 7 & 8 & 9 \\
10 & 11 & 12 & 13 & 14 & 15 & 16 \\
17 & 18 & 19 & 20 & 21 & 2223 \\
2 & 25 & 2627 & 28 & 29 & 30\end{array}$ & $\mid \begin{array}{ccccccc}* & 1 & 2 & 3 & 4 & 5 & 6 \\
7 & 8 & 9 & 10 & 11 & 12 & 13 \\
14 & 15 & 16 & 17 & 18 & 1920 \\
21 & 22232 & 22 & 252627 \\
28 & 2930 & \cdots & \ldots\end{array}$ \\
\hline MAY & JUN & WUL & $A L S$ \\
\hline 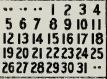 & 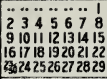 & 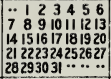 & $\begin{array}{ccccccc}\ddot{4} & \ddot{5} & \mathbf{6} & \ddot{7} & \mathbf{8} & 2 & 3 \\
4 & 9 & 1 \\
11 & 12 & 13 & 14 & 15 & 16 & 17 \\
18 & 1920 & 21 & 222324 \\
252627 & 282930\end{array}$ \\
\hline SEEP & OCT & NOV & DEC \\
\hline $\begin{array}{ccccccc}1 & 2 & 3 & 4 & 5 & 6 & 7 \\
8 & 9 & 10 & 11 & 12 & 13 & 14 \\
1516 & 1718192021 \\
2223224252627 & 28 \\
2930 & \ldots & \cdots\end{array}$ & $\begin{array}{ccccccc}\because & 0 & 1 & 2 & 3 & 4 & 5 \\
6 & 7 & 8 & 9 & 10 & 11 & 12 \\
13 & 14 & 15 & 16 & 17 & 1819 \\
20 & 21 & 222324 & 2526 \\
27 & 28 & 29 & 30 & 31 & \cdots & \cdots\end{array}$ & $\begin{array}{ccccccc}\because & 3 & \cdots & \cdots & 1 & 2 \\
3 & 4 & 5 & 6 & 7 & 8 & 9 \\
10 & 11 & 12 & 13 & 14 & 15 & 16 \\
17 & 18 & 1920 & 20 & 2223 \\
2425 & 2627 & 28 & 29 & 30\end{array}$ & 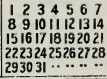 \\
\hline
\end{tabular}

Table of Pounds to Bushel.

Wheat, - 60 Millet seed, - 50 Apples, dried, - 24 Corn, shelled, - 56 Red Top, - - 14 Peaches, dried, - 33 Corn, ear, - - 70 Blue Grass, - 14 Cranberries, - 33 Corn, in husk, - 74 Orehard Grass, -14 Corn Meal, - 48 Oats, - . - 32 Hungarian, . 45 Bran, - . 20 Rye, - - 56 White Beans, - 60 Malt, - - 38 Barley, - - 48 Castor Beans, - 46 Salt, . . 65 Buckwheat. - 52 Peas, . . - 60 Stone Coal, - 80 Pop Corn, - - 70 Potatoes - - 60 Charcoal, - 22 Cloverseed, . -60 Sweet Potatoes, 55 Coke, - . . 40 Timothy seed, - 45 Onions, - - 57 Lime, - . 80 Flax seed, - 56 Turnips, - 55 Flour, bbl. . 196 Hempseed, - 44 Apples, green, - 56 Flour, sack, - 49 
ELBERTA. A Georgia cross between Crawford's and Chines Cling, very large, well colored; all things considered, the finest yellow freestone in cultivation. Tree a strong, vigorous grower, and thrives well all over the peachgrowing belts of the world. One of the most successful shipping varieties. Ripens in Middle Georgia, where it originated, July 15th to 20 th.

EARLY RIVERS. An old well-known variety; large, light straw color, with delicate pink cheek; flesh juicy and melting, with very rich flavor. Season first of July. Free.

FAMILY FAVORITE. Large, roundish, inclined to oblong; color golden yellow, with waxen complexion and blush cheek; suture shallow. Flesh yellow, with red streaks near the pit; firm, juicy, with high aromatic flavor. Cling. A seedling of Chines Cling of far better color than the parent. Commercial in the Southwest. Origin, Texas.

FOSTER. Large, roundish; color bright yellow shaded with dark red; suture slight in compression, extending two-thirds around. Flesh bright yellow, slightly red at pit; juicy, vinous, tender, much like Early Crawford, but better in quality; pit free. Grown in Ohio and eastward. Origin, Massachusetts.

GREENSBORO. Medium to large, round; color yellow with red and crimson cheek: Flesh white, very juicy; good. A North Carolina variety larger than Alexander and earlier in season. Cling.

HEATH'S CLING. Very large, oblong, narrowed at both ends with decided points at the top; color yellowish white with red cheek in interior climates; suture distinct, extending to apex. Flesh greenish white, tender, melting; quality nearly best. Pit not free. Origin, Maryland.

HENRIETTA. Very late. Very large, roundish, somewhat depressed; color bright yellow, with crimson cheek; cavity medium, 
deep. Flesh yellow, quite firm; sweet, vinous, very good; pit not free. An old variety, popular in Southwestern states. Origin, District of Columbia.

J. H. HALE. A new peach originated by the famous peach king, J. H. Hale of Fort Valley, Ga. This great peach is destined to become one of the leading commercial varieties. It is a large Yellow Freestone, coming in just a little ahead of Elberta, better in quality, as large as Elberta, round and highly colored all over with deep red.

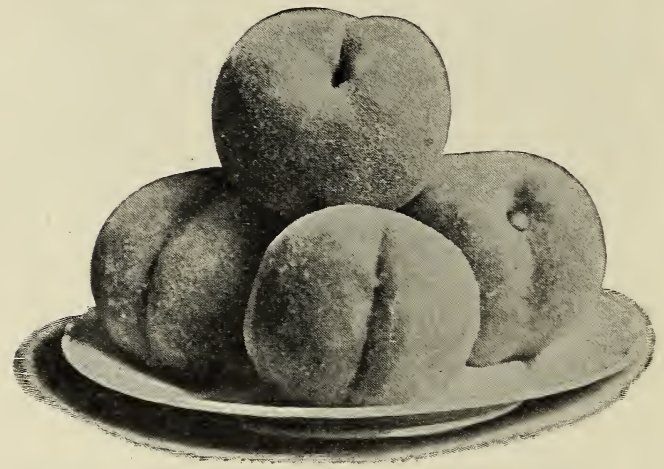

Belle of Georgia

KRUMMEL OCTOBER. A magnificent peach-the most profitable and best late Yellow Freestone, which ripens about two weeks after Salway, or four weeks after Elberta. Large, almost round, deep yellow, with a dark carmine blush; very firm, fine texture. Tree a very strong grower, vigorous and healthy. Fruit hangs very late-for weeks-without decaying.

LEMON CLING. Large, oblong, narrowed at the top with projecting enlarged point like a lemon; color yellow, with brownish red cheek. Flesh yellow, with red at the pit, vinous, subacid, very good; pit not free. Origin, South Carolina. 
LEMON FREE. Large, roundish ovate, often with pointed apex; color light yellow, with greenish white tinge and thick bloom; cavity quite deep; suture not distinct, but flesh at one side elevated. Flesh yellow, tender, somewhat dry, good; pit free. Grown mainly for canning. Origin, Ohio.

MAYFLOWER. A gloriously beautiful "red all over" peach, so handsome and of such splendid quality that it tops all markets. Every commercial orchardist should plant them - they should be in every home garden everywhere. Extremely early, tree hardy and healthy. Since the acquisition of Mayflower with its remarkable record made in the great orchards of the veteran peach grower, J. Van Lindley of North Carolina; (the introducer of Greensboro), we have discarded such sorts as Victor, Sneed and others of that class.

MOTLOW (J. C. Hale). This is a new peach introduced by the writer. Large, yellow, freestone, equally as large as Elberta; ripens about ten to fifteen days later. Fine quality, tree a very vigorous grower and prolific bearer. Old original tree still standing in the Widow Motlow's backyard in Winchester, twenty-five years old, and at least twenty-five feet tall. Great, to follow Elberta. Commercial.

MAMMOTH CLING. Resembling Heath's Cling, but double its size. Originated in Southern Missouri. Season, September. Quality good to best.

MOUNTAIN ROSE. Large, red flesh, white, rich, juicy, excellent; one of the best early peaches, ripening with Troth's Early, and a much larger and finer variety; should be in every collection. July. Free.

MUIR. Large, roundish, oval, somewhat compressed; color yellow, white reddish cheek and splashes of red and crimson; cavity broad and quite deep; suture extends to apex. Flesh yellow, tender, sprightly; pit free. A cosmo- 
politan variety, doing well over the peach sections of the Union. A good shipper and canner, and particularly adapted to drying. Origin, California.

NIAGARA. A variety grown in Western New York, supposed to be a seedling of Early Crawford, which is larger in size; quite as productive and ripens later than its parent; pit free. Fruit, large yellow and excellent in quality. Now grown commercially.

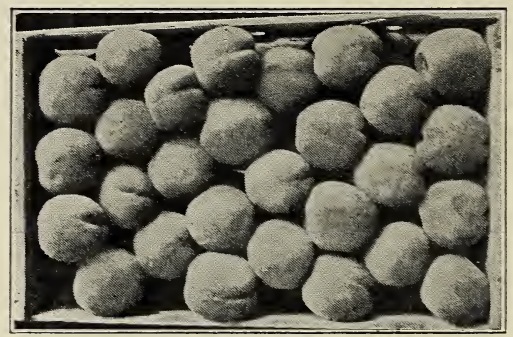

J. H. Hale

OLD MIXON CLING. Large, roundish oval; color yellowish white, dotted with red and often with red cheek. Flesh juicy, rich, with best flavor. Widely known as one of the best of the clingstone varieties.

OLD MIXON FREE. Medium to large, roundish, somewhat oval, with one side largest; color creamy white, marbled with red and with bright red cheek. Cavity narrow; suture slight. Flesh creamy white with red at pit; tender, vinous, very good; pit free. An old variety, yet starred in several states.

PICQUETT'S LATE. Large, round, color yellow with red cheek; cavity narrow and deep; suture slightly elevated at apex. Flesh yellow; with red at pit, firm, sprightly, good to very good, pit free. Widely grown in the South, and a favorite in California. Origin, Georgia. 
REEVES' FAVORITE. Medium to large, roundish, and inclined to ovate; color yellow; with dark red cheek and thin bloom; cavity deep and broad; suture not distinct. Flesh yellow, with red at pit; mild, vinous, good. Grown in the South and Eastern States. Origin, New Jersey.

RED BIRD CLING (Early Wheler). Earliness, high color, and good quality make it very valuable. Very large for an early peach, averaging almost as large as Mamie Ross and Carman. Creamy white overspread with a bright, glowing red; the first extra early good shipping peach on the list. Should be planted largely. Cling.

SALWAY. Large, roundish, somewhat oval, with one side largest; color yellow, with red cheek and bloom; suture slight, extending beyond apex. Flesh yellow, with red at pit, juicy, tender, vinous, good; pit free. An old English variety, commercially planted in many states for late marketing.

SLAPPY. Medium, roundish; color bright golden yellow, with red and crimson shades. Flesh yellow, sweet, almost luscious; pit free. The earliest handsome and good peach shipped north from Alabama and Georgia. Origin, Georgia.

SMOCK FREE. Large, roundish, inclined to ovate; color yellow, with some blush on cheek and heavy bloom; cavity narrow and deep; suture obscure except near apex, which is slightly extended. Flesh yellow, with red at pit, quite tender, and sprightly; quality good; pit free. Commercial. Origin, New Jersey.

SNEED. Medium, roundish oval, compressed; color creamy white, splashed and mottled with bright red, with some bloom; cavity narrow and deep. Suture extends beyond the apex. Flesh yellowish white, tender, vinous, good; pit nearly free. Free from rot and ripens very early. Origin, Tennessee. 
STEVENS (Stevens' Rareripe). Medium to large, roundish ovate; color, creamy white with dark red cheek and some bloom; cavity narrow and quite deep; suture slight and extending beyond apex. Flesh yellowish white, with some red at pit; tender, sprightly, good; pit free. A popular late variety. Origin, New Jersey.

TUSKEN CLING. Very large, roundish or roundish oval; color yellow with dark red cheek and bloom; cavity narrow and deep; suture extends past the apex. Flesh yellow, with red at pit; juicy, vinous, rich, very good. Pit not free. Mainly grown in Utah and on the West Coast, but it thrives well in the South.

UNEEDA. Clear white, beautifully blushed, very handsome, attractive and high in quality. Hardy in tree and bud and a vigorous grower. One of the best clings of its season-as beautiful as a perfect Heath's Cling and surprisingly early for such a large and handsome peach. Growing in demand with commercial planters in the South. Origin, Georgia.

VICTOR. Medium, roundish. Flesh pleasant; subacid; pit not free. A seedling of Chines Cling crossed with Spanish Blood, of value on account of its extreme earliness, often maturing its fruit in the South by the middle of May.

WONDERFUL. Large, roundish oval; color yellow with carmine blush of cheek and some bloom; cavity narrow and deep; suture extends beyond apex. Flesh yellow, with red at pit, quite tender, and high flavored; pit free. New, but growing in popularity at the Southwest for late shipment and home use. 

